\title{
Momordica Charantia L. Variety from Northeastern Brazil: Analysis of Antimicrobial Activity and Phytochemical Components
}

\author{
William Antonio Sagástegui Guarniz',8, Kirley Marques Canuto2, Paulo Riceli Vasconcelos Ribeiro², Hilania Valeria \\ Dodou ${ }^{1}$, Karla Nascimento Magalhaes ${ }^{3}$, Kellen Miranda Sá3 ${ }^{3}$ Patrícia Georgina Garcia do Nascimento ${ }^{4}$, Karine Lima Silva ${ }^{5}$, \\ Gleilton Weyne Passos Sales ${ }^{6}$, Mirian Parente Monteiro', Nadia Accioly Pinto Nogueira ${ }^{1}$, Sikiru Olaitan Balogun ${ }^{7, *}$, Mary \\ Anne Medeiros Bandeira ${ }^{1}$
}

William Antonio Sagástegui Guarniz $^{1,8}$, Kirley Marques Canuto ${ }^{2}$, Paulo Riceli Vasconcelos Ribeiro², Hilania Valeria Dodou', Karla Nascimento Magalhaes ${ }^{3}$, Kellen Miranda Sá ${ }^{3}$, Patrícia Georgina Garcia do Nascimento ${ }^{4}$, Karine Lima Silva ${ }^{5}$, Gleilton Weyne Passos Sales $^{6}$, Mirian Parente Monteiro', Nadia Accioly Pinto Nogueira ${ }^{1}$, Sikiru Olaitan Balogun ${ }^{7, *}$, Mary Anne Medeiros Bandeira ${ }^{1}$

'Department of Pharmacy, Faculty of Pharmacy, Odontology and Nursing, Universidade Federal do Ceará, Ceará, BRAZIL. 'Embrapa Agroindústria Tropical, Ceará, BRAZIL.

${ }^{3}$ Horto de Plantas Medicinais Prof FJA Matos, Universidade Federal do Ceará, BRAZIL. ${ }^{4}$ Department of Chemistry, Faculty of Chemistry, Universidade Federal do Ceará, Ceara, BRAZIL.

${ }^{5}$ Department of Medicine, Faculty of Medicine, Universidade Federal do Ceará, Ceará, BRAZIL. ${ }^{6}$ Departamento de Análises Clínicas e

Toxicológicas, Universidade Federal do Ceará, Ceará, BRAZIL.

${ }^{7}$ Faculdade Noroeste do Mato Grosso-AJES, 78.320-000, Juína, Mato Grosso, BRAZIL. ${ }^{8}$ Department of Pharmacology, Faculty of Pharmacy and Biochemistry, National University of Trujillo, PERU.

\section{Correspondence}

\section{Sikiru Olaitan Balogun}

Faculdade Noroeste do Mato Grosso - AJES, 78.320-000, Juína, Mato Grosso, BRAZIL.

E-mail: balogun.zhikrullah@gmail.com History

- Submission Date: 15-07-2019;

- Review completed: 14-08-2019;

- Accepted Date: 14-08-2019.

DOI : 10.5530/pj.2019.11.203

Article Available online

http://www.phcogj.com/v11/i6

\section{Copyright}

(C) 2019 Phcogj.Com. This is an openaccess article distributed under the terms of the Creative Commons Attribution 4.0 International license.

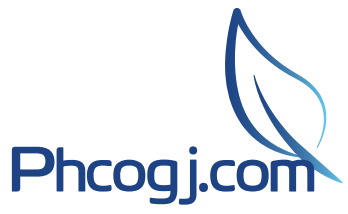

\section{ABSTRACT}

Introduction: Momordica charanthia L., Curcubitaceae, is a pantropical food and medicinal plant. The plant is included in the Official List of Brazilian Medicinal Plants of interest to the Brazilian Unified Health System. The study aimed to perfom microbiological studies with extracts of Momordica charanthia L. including chemical characterization of the active extracts. Methods: The antimicrobial activity was evaluated with the hydroalcoholic and acetone extracts of $M$. charantia leaves, fruits and seeds from northeastern Brazil using microdilution broth technique on the selected clinical bacterial and fungal strains. Extracts that presented antimicrobial were subjected to ultra performance liquid chromatography-quadrupole time-of-flight mass spectrometry (UPLC-QToF-ESI-MS). Results: The in vitro antimicrobial assays demonstrated that the leaves extracts presented good antibacterial effect against four Staphylococcus aureus strains, and a weak antifungal activity agaist Candida albicans. Fourteen compounds were identified in the hydroalcoholic extract, while 12 were found in the acetone extract. The most important compounds were kaempferol, quercertin and triterpenoids like cucurbitacins. Conclussion: The present study demonstrated the potential antibacterial activity of $M$. charantia L. from northeastern part of Brazil, in addition to important phytochemical metabolites known to possess antibacterial activities, particularly against microrganisms of clinical importance. The UPLC phytochemical profile of the Brazilian variety is reported here for the first time. The phytochemical profile of the LHE and FAE demonstrated the presence of biologically and pharmacologically active compounds. There is lack of biological and pharmacological studies to support the medicinal uses of this important plant. The Brazilian variety of $M$. Charantia could be a potential therapeutic agent in the treatment of infections.

Key words: Ethnopharmacology, in vitro activity, Antibacterial, Antifungal.

\section{INTRODUCTION}

Momordicacharantia L. belongs to the cucurbitaceae family is a climbing plant found frequently covering fences and shrubs along the paths from north to south regions of Brazil, especially during the rainy season. It is a species native to Africa that was introduced to South America in the colonial period by black slaves from the African continent. ${ }^{1,2}$

Momordica charantia is found in nature in various forms distinguishable by the size of the fruits. Two of which are more frequent the northeastern Brazil, where it is popularly reffered to as the Melãode-Caetano, erva-de-lavadeira "laundry-plant", because the whole plant is used in the washing of clothes in the rural areas. A variety of large fruits that can measure up to $30 \mathrm{~cm}$ in length and about 5 $\mathrm{cm}$ in diameter is the most common variety in the Asian countries, used both in food and in medicinal preparations. This variety was introduced to Brazil in this century, and its fruits can readily be found in the open markets like in the state of São Paulo (Figures 1 and 2). ${ }^{3}$
In the state of Ceará, northeastern Brazil, one of the earliest records of $M$. charantia is found in the Coleção Descritiva das Plantas da Capitania do Ceará do Naturalista Feijó "Descriptive collection of Plants of Cearáregion" by João da Silva Feijó, who was a Ceará naturalist in $1818 .{ }^{4}$ As at that time, Brazil was still under Portuguese colonization. However, other works on northeastern Brazillian Flora by the naturalist Freire Allemão, who also recorded the species, were based on this collection..$^{5}$ In the twentieth century, the ethnobotanical descriptions of $M$. charantia, including its use in the popular medicine of the northeast, can be encountered in important works like the Formulário Fitoterápico (Phytotherapeutic Formulary) of Professor Dias da Rocha ${ }^{6}$ Plantas do Nordeste, especialmente do Ceará (Plants of the Northeast, especially of Ceará). ${ }^{7}$ and Plantas da Medicina Popular do Nordeste (Plants of the Northeastern People's Medicine). ${ }^{8}$

In the Brazilian state of Ceará, the plant is used topically in compresses, plasters, washes for the treatment of ulcers and various skin disorders

Cite this article: Guarniz WAS, Canuto KM, Ribeiro PRV, Dodou HV, Magalhaes KN, Sa KM, et al. Momordica Charantia L. Variety from Northeastern Brazil: Analysis of Antimicrobial Activity and Phytochemical Components. Pharmacog J. 2019;11(6):1312-24. 


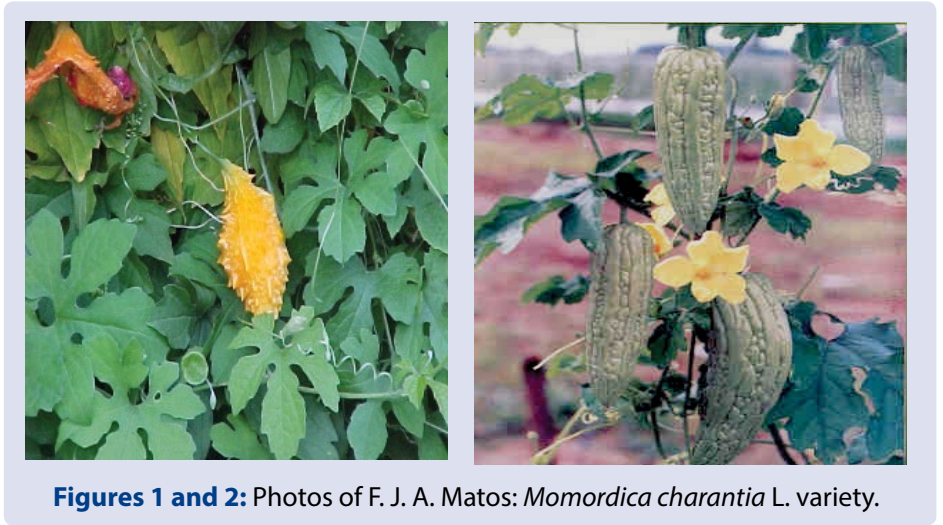

(abscesses, boils, pediculosis, pruritus and burns). And recently, its ethnomedicinal uses from the same region was detailed in the Ethnopharmacopoeia of Professor Francisco José de Abreu Matos ${ }^{9}$ which included wound healing, as antiseptic, treatments of gonorrhea, skin diseases, colitis, gynecological inflammation, external tumor, vaginal discharge, infected wounds and for weight loss. The plant parts used are theleaves (its juice, natural form or as poultice, decoction and maceration in water, fruit (natural form or as poultice, its branch and the whole plant). It is also prepared in form of tintures/alcohol extract and is employed externally to treat skin infections or parasite infestations. ${ }^{10,11}$

This plant has received a lot of attention due to its many ethnomedicinal and culinary uses. Biological and pharmacological studies of $M$. charantia have shown interesting therapeutic potentials, particularly its antidiabetic ${ }^{12-17}$, antileishmania ${ }^{18}$, antiHIV $^{19}$, analgesics and anti-inflammatory activities. ${ }^{20}$ In addition, pharmacological and biological action of its various metabolites have been cited. ${ }^{21,22}$

Due to the ethnomedicinal importance of the local Brazilian variety, this species has been included in the National List of Medicinal Plants of Interest to Brazilian Public Health System ${ }^{23}$ and is also part of the Official List of Medicinal Plants of Ceará, a northeastern state of Brazil (REPLAME-CE). ${ }^{24}$ The plant also featured in the Brazilian Pharmacopoeia Phytotherapeutics Formulary. ${ }^{25}$ Although, the antimicrobial properties of varieties other than that from Brazil have been cited in many studies using varying biological and pharmacological models, extracts from varying solvents ${ }^{26-28}$, few studies have been done on $M$. charantia antimicrobial activities collected in the northeastern region of Brazil. ${ }^{29,30}$ To the best of our knowledge, there is no detailed phytochemical studies of this important medicinal and food plant of thislocal variety from northeastern region of Brazil, despites being part of the Official Plant Lists. It is on this basis that we conducted the present study to establish scientific proof for its popular use in treating infections, to standardize extract with promising antibacterial activity and relate its metabolites content based on literature sources to it ethnomedicinal uses by people inhabiting northeastern region (Caatinga Biome) of Brazil.

In this study, we reported the antimicrobial activity of six extracts (hydroethanolic and acetone extracts of $M$. charantia leaves, fruits and seeds) obtained from the northeastern region of Brazil in order to justify its popular use, in addition to conducting phytochemical profile of the most promising extracts.

\section{MATERIALS AND METHODS}

\section{Chemicals and reagents}

Brain heart infusion media and Agar Sabouraud Dextrose (Kasvi), Müller-Hinton agar, methanol, trichloroacetic acid, ascorbic acid, potassium phosphate buffer, acetonitrile, ethanol, and methanol, used were hypergrade for LC-MS LiChrosolv ${ }^{\star}$ and are products of MerkKGaA, Germany. Others such as formic acid $98-100 \%$ and n-Hexane were also purchased from MerkKGaA, Germany. Dimethylsulfoxide (Biology applications grade, Sigma-Aldrich, Inc), Oxacilin and fluconazol (Sigma Chemical Company, St. Louis, MO, USA.

\section{Botanical material}

The plant was collected from the Medicinal Plants Garden of Prof. Francisco José de Abreu Matos, Universidade Federal do Ceará, in the flowering and fruiting period, precisely in June 2018. The herbarium specimens' were deposited in the Herbarium Prisco Bezerra the Universidade Federal do Ceará with specimen voucher number EAC31609 and identified as Momordica charantia L. For the preparation of the extracts, the leaves, fruits and seeds were submitted to drying in an air circulating oven at $45^{\circ} \mathrm{C}$ until constant weight, then milled with the aid of a knife mill.

\section{Preparation of leaf, fruit pulp and seeds extracts for microbiological tests}

Two extractions were performed for each part of the plant, with ethanol/ $\mathrm{H}_{2} \mathrm{O}(7: 3)$ and with acetone. $0.80 \mathrm{~g}$ of the leaf powder, fruit pulp and seed were weighed separately, and placed in a test tube with $4 \mathrm{~mL}$ hexane for degreasing. Subsequently, $4 \mathrm{~mL}$ of ethanol/ $\mathrm{H}_{2} \mathrm{O}$ solution (7: 3) was added, homogenized and the polar compounds extracted in an ultrasonic bath for another $20 \mathrm{~min}$ with fixed power (135 W). The samples were then centrifuged (3000 rpm/10 minutes). Thehexanic phase was discarded. The hydroethanolic phase (ethanol/ $\mathrm{H}_{2} \mathrm{O}$ ) was filtered on a $0.22 \mu \mathrm{m}$ PTFE (polytetrafluoroethylene) filter, and thereafter the filtrate was collected in small vials, with subsequent drying and weighing.

For the extraction with acetone, the same procedure was performed, except that before adding acetone the hexanic phase was removed.

Thus, six extracts were obtained and coded as follows: Leaves hydroethanolic extract/ethanol/ $\mathrm{H}_{2} \mathrm{O}$ (LHE) and acetone extract (LAE); Fruits - ethanol/ $\mathrm{H}_{2} \mathrm{O}$ extract (FHE) and acetone extract (FAE); Seeds- ethanol $/ \mathrm{H}_{2} \mathrm{O}$ extract (SHE) and acetone extract (SAE). All these samples were dried and weighed to calculate their yields.

To evaluate the antimicrobial action, the extracts were dissolved in $1 \%$ dimethyl sulfoxide solution (DMSO, Merck).

\section{Microorganisms}

All bacterial and fungal strains used in in vitro experimental models were obtained from the collection of the reference microorganisms used in Sanitary Surveillance (CMRVS, FIOCRUZ-INCQS, Rio de Janeiro) and were maintaned in the Applied Microbiology Research Laboratory of Universidade Federal do Ceará. These are Staphylococcus aureus 
ATCC 14458 (oxacillin sensitive), S. aureus CCBH 5330 (oxacillin resistant and methicillin resistant strain MRSA), Staphylococcus epidermidis ATCC 35984, Pseudomona aeruginosa ATCC 9027 and Candida albicans ATCC 10231.

To prepare the microbial inoculum, the strains were cultured in Brain Heart Infusion (BHI) broth for bacteria or Sabouraud broth for yeasts. Subcultures were incubated for 24 hours at $37^{\circ} \mathrm{C}$. For standardization of the inocula, aliquots taken from the subcultured tube were transferred to $0.85 \%$ sterile saline to otained turbidity equivalent to the McFarland 0.5 scale (about $10^{8} \mathrm{CFU} / \mathrm{mL}$ or $10^{6} \mathrm{CFU} / \mathrm{mL}$ for bacteria and yeast, respectively). This suspension was diluted to obtain the final microbial colony forming units (CFU) of $10^{6} \mathrm{CFU} / \mathrm{mL}$ for bacteria or $10^{4} \mathrm{CFU} /$ $\mathrm{mL}$ for yeasts, and which were used in all the microbiological assays.

The determination of the Minimum Inhibitory Concentration (MIC) was performed according to the methodology recommended by the Clinical and Laboratory Standard Institute. ${ }^{31,32}$ In the 96-well, sterile microplates, $100 \mu \mathrm{L}$ of culture medium (BHI broth for bacteria or Sabouraud for yeast), $20 \mu \mathrm{L}$ of the sample (extract), were added in serial concentrations ranging from 2000.0 to $31.2 \mu \mathrm{g} / \mathrm{mL}$ and $80 \mu \mathrm{L}$ of the microbial suspensions $\left(10^{6}\right.$ and $10^{4} \mathrm{CFU} / \mathrm{mL}$, for bacteria and yeast, respectively). Controls of turbidity, medium sterility, microbial growth, diluent sterility and inhibition by the diluent were performed. As positive controls, oxacillin and fluconazole were used for bacteria and yeasts, respectively, at concentrations ranging from 0.0488 to 100 $\mu \mathrm{g} / \mathrm{mL}$.

The microplates were incubated for 24 hours at $37^{\circ} \mathrm{C}$ and after this period, the visual reading of bacterial growth was carried out. MIC was determined as the lowest concentration of test substance capable of inhibiting microbial growth to the naked eye, as evidenced by the absence of turbidity. ${ }^{31,32}$

For extracts with intense turbidity, $10 \mu \mathrm{L}$ of resazurin $(0.01 \%)$ was added and incubated at $37{ }^{\circ} \mathrm{C}$ for 2 hours. The maintenance of the blue color in the wells was interpreted as absence of bacterial growth, and the development of pink color, as occurrence of bacterial growth. The MIC was defined as the lowest concentration of the test substance in which there was no change in coloration. ${ }^{33}$ The experiments were performed in triplicate and at two different times.

For determination of Minimum Bactericidal Concentration (MBC), 5 $\mu \mathrm{L}$ aliquots of microplate wells used to determine MIC that did not show bacterial growth were seeded in Petri dishes containing plate count agar and incubated for 24 hours at $37^{\circ} \mathrm{C}$. After this period, colonies were counted. MBC was considered as the lowest concentration capable of inhibiting bacterial growth by at least $99.9 \%$ of the initial inoculum. ${ }^{34,35}$

Analysis by ultra-performance liquid chromatographyquadrupole time-of-flight mass spectrometry (UPLC-QTOF-ESIMS)

Phytochemical analysis was performed only on extracts that presented significant antimicrobial activity. The extracts were prepared as described in Section 2.2 for UPLC analysis. After filtration in $0.22 \mu \mathrm{m}$ PTFE filters, each extract was withdrawn and $100 \mu \mathrm{L}$ of the standard internal solution (anthracene-9-carboxylic acid) was added at a concentration of $10 \mu \mathrm{g} / \mathrm{mL}$ (10 ppm). Only LHE and LAE extracts were subjected to UHPLC analysis.

The analysis was performed in Acquity UPLC system (Waters), coupled to a Quadrupole / Flight Time (QToF, Waters) system. Chromatographic runs were performed on a Waters Acquity UPLC BEH column (150 x $2.1 \mathrm{~mm}, 1.7 \mathrm{um}$ ), fixed temperature of $40{ }^{\circ} \mathrm{C}$, mobile water phases with $0.1 \%$ formic acid (A) and acetonitrile with $0.1 \%$ formic acid (B), gradient ranging from $2 \%$ to $95 \%$ ( $15 \mathrm{~min}$ ), flow rate of $0.4 \mathrm{~mL} / \mathrm{min}$ and injection volume of $5 \mu \mathrm{L}$. High-resolution mass conditions - XEVO-
QToF. The ESI-mode was acquired in the range of 110-1180 Da, fixed source temperature at $120^{\circ} \mathrm{C}$, desolvation temperature 350 RegularC, withdrawal gas flow of $500 \mathrm{~L} / \mathrm{h}$, extraction cone of $0.5 \mathrm{~V}$, capillary voltage of $2.6 \mathrm{kV}$. ESI + mode was acquired in the range of $110-1180$ $\mathrm{Da}$, source temperature 120 fixed RegularC, desolvation temperature $350{ }^{\circ} \mathrm{C}$, desolvation gas flow $500 \mathrm{~L} / \mathrm{h}$ and the capillary voltage of $3.2 \mathrm{kV}$. Leucine encephalin was used as a lock mass. The acquisition mode was MSE. The instrument was controlled by Masslynx 4.1 software (Waters Corporation).

The software used for data processing was the Masslynx (Waters Corporation) where the molecular formulas were calculated with their respective masses. The identification of the compounds was made based on comparison of spectral patterns already discussed in the literature regarding the species of $M$. charantia. In addition, online databases containing information on characterized metabolites such as Scifinder, Knapsack, PubChem and Chemspider were also consulted.

\section{RESULTS AND DISCUSSION}

\section{Extracts yields}

The yields of the six extracts, previously encoded, were as follows: LHE 9.8\%, LAE 4.2\%, FHE 17\%, FAE 5.2\%, SHE 13\% and SAE 5.4\%.

\section{Microbiological assays}

The only extracts that presented significant antimicrobial activity were those of the leaves, which are LHE and LAE, and therefore data for extracts without activity were not shown in the Table 1.

In the present study, antimicrobial activity of LHE and LAE was detected against four of the five clinically important bacterial and fungal isolates. The highest effect was observed for the acetone extract (LAE) (Table 1).

According to Aligiannis et al. ${ }^{36}$, MIC values $<0.5 \mathrm{mg} / \mathrm{mL}$ are considered potent inhibitors; MICs between 0.6 and $1.5 \mathrm{mg} / \mathrm{mL}$ are moderate inhibitors; and MIC> $1.6 \mathrm{mg} / \mathrm{mL}$ are weak inhibitors. Thus, the LAE extract is a potent inhibitor on strains of $S$. aureus, moderate on $S$. epidermidis and weak on yeasts (C. albicans). The antibacterial activities of extracts and fractions prepared from different parts of $M$. charantia have been reported from various parts of the world..$^{28-30,37,38}$ The parts with reports of antimicrobial activities include the fruits, seeds, leaves and the stems. However, it is interesting to note that comparison based on literature reports is difficult based on many reasons. Sometimes, the minimal concentrations employed are in excess of up to 10 times the maximum concentration that we employed or even difficult to deduce $^{37,38}$, in some others the concentrations were not stated, but rather the activity stated ${ }^{38,39}$ and there seems not to be any clear criteria for reporting plants' extracts antimicrobial activities in many cases. ${ }^{37,39}$ in addition, the solvents or the methods employed are completely different. ${ }^{37,39,40}$

On this basis, true comparison of the activities reported on $M$. charantia from different parts of the world seem to be a daunting and a very difficult task. In the case of divergent in the activities reported for the plants with similar methods used, the differences in the activities reported can be due to one of or combination of the following reasons: variations in the seasons of collections, temperature, water availability, ultraviolet radiation, nutrients availability, atmospheric pollution, mechanical damage, and pathogen attacks. ${ }^{4}$ These external differences invariably influence the composition and levels of important secondary metabolites of the plant materials employed in these different studies, in addition to the variations related to methodological approaches in the antimicrobial assays. ${ }^{42}$

LHE extract, on the other hand, is a potent inhibitor of $S$. aureus strains, but moderate on $S$. epidermidis. The differences observed in the 
antimicrobial potential between LAE and LHE extracts on strains of Staphylococcus may be due to the differences in metabolites composition of both extracts. Some cucurbitacins have been shown to have in vitro antibacterial activities. ${ }^{43-46}$ An excellent review on cucurbitacins and its derivatives was made by Jian et al. ${ }^{47}$ Interested reader would find the review interesting.

\section{Identification of chemical constituents of the} hydroethanolic and acetone extracts (LHE and LAE)

The major chemical constituents of $M$. charantia leaves are the tetracyclic triterpenoids and their glycosides, most of which are referred to as cucurbitans, and are known for their bitterness and biological effects, in addition to quercetins and kaempferols.

The cucurbitacins belong to a class of plant triterpenic, tetracyclic compounds and highly oxygenated derivatives cucurbitane skeleton. Cucurbitane-like molecules have several polarities due to the variation of substitutions in the side chain or portions of glucose or rhamnose $e^{47-56}$. Several compounds were isolated from extracts of $M$. charantia by separations involving chromatographic processes, which served as reference in the identification of the chemical constituents of the present study.

The chromatograms of the hydroethanolic (LHE) and acetone (LAE) extracts obtained in the positive ionization mode are shown in Figures $3 \mathrm{~A}$ and $\mathrm{B}$, respectively. The characterized compounds are summarized in Table 2 with the relevant data, including retention time, experimental mass and calculated $\mathrm{m} / z$, molecular formula, error in ppm provided by the software and the MS/MS fragments. Chemical profile of the extracts afforded the tentatively identification of 14 compounds. These are one amino acid, four flavonoids and nine triterpenoids derivatives.
A brief comparison between the hydroethanolic extract and acetone extract of the leaves of $M$. charantia revealed some striking differences. Tryptophan, quercetin and kaempferol hexoside were found only in the LHE extract, while LAE extract presented two unknown compounds, Table 2.

Tryptophan was identified by the precursor ion at $\mathrm{m} / \mathrm{z} 205$ $\left(\mathrm{C}_{11} \mathrm{H}_{13} \mathrm{~N}_{2} \mathrm{O}_{2}\right)$ and the characteristic fragment at $\mathrm{m} / z 130$ (indol nucleus). ${ }^{57}$ Quercetin- $O$-hexoside isomers showed a precursor ion at $m / z 465\left(\mathrm{C}_{21} \mathrm{H}_{21} \mathrm{O}_{12}\right)$ and a product ions at $m / z 303$, key fragment of quercetin aglycone, resulted from the loss of glucose unit. Additionally, quercetin-O-rhamnoside shows a typical precursor ion $m / z 449\left(\mathrm{C}_{21} \mathrm{H}_{21} \mathrm{O}_{11}\right)$ and the characteristic fragment at $\mathrm{m} / z 303$, loss of rhamnose. ${ }^{64}$ Kaempferol-O-hexoside showed an $\mathrm{m} / z$ at 449 $\left(\mathrm{C}_{21} \mathrm{H}_{21} \mathrm{O}_{11}\right)$, with a key fragment of the kaempferol nucleus at $m / z 287$ indicated by the loss of a hexose. Prior studies have identified these compounds in M. charantia. ${ }^{58,65,66}$

Curburbitane-type triterpenes were identified due the losses of $\mathrm{H}_{2} \mathrm{O}$ $(18 \mathrm{Da}), \mathrm{CO}(28 \mathrm{Da})$ as well as because of a diagnostic fragment ion at $\mathrm{m} / z 109$ resulting from the break of C17-20 linkage. Thus, hydroxycucurbitatetraenal isomers were identified by the precursor ion at $m / z 437\left(\mathrm{C}_{30} \mathrm{H}_{45} \mathrm{O}_{2}\right)$ and its product ions at $m / z 419,409,391$, 109. An example of this fragmentation pattern occurs with the $3 \beta$-hydroxycucurbita-5 (10), 6,22 (E), 24-tetraen-19-al, Figure 4, as previously reported in $M$. charantia. ${ }^{59-63,67}$ Epoxy isomers showed an additional oxygen $(16 \mathrm{Da})$ and same fragmentation pattern. The Figure 5 depicts the MS fragmentation to $5 \beta, 19$-epoxycurcubita6,22(E),24-triene-3 $\beta, 19$-diol ${ }^{59,61}$, and 3-[(5-formyl-7 $\beta, 25$ dihydroxymethoxycucurbita-5,23-dien-3-yl)oxy]-3-oxopropanoic acid $^{62}$, Figure 6 .

Table 1: Minimum Inhibitory Concentration (MIC) and Minimum Bactericidal Concentration (MBC), in $\mathrm{mg} / \mathrm{mL}$, of EtOH/ $\mathrm{H}_{2} \mathrm{O}$ and acetone extracts of $M$. charantia.

\begin{tabular}{cccc}
\hline Microorganism & & Leaves extracts & \\
& LHE & LAE & MBC \\
\cline { 2 - 4 } & MIC & MIC & - \\
S. aureus ATCC 14458 & 0.5 & 0.25 & 2.0 \\
S. aureus CCBH 5330 & - & 0.125 & - \\
S. epidermidis ATCC 35984 & 2.0 & 1.0 & - \\
P. aeruginosa ATCC 9027 & - & - & 2.0 \\
C. albicans ATCC $\mathbf{1 0 2 3 1}$ & - & 2.0 & \\
\hline
\end{tabular}

LHE: leaves hydroethanolic extract (ethanol/ $\mathrm{H}_{2} \mathrm{O}, 7: 3$ ); LAE: acetone extract.

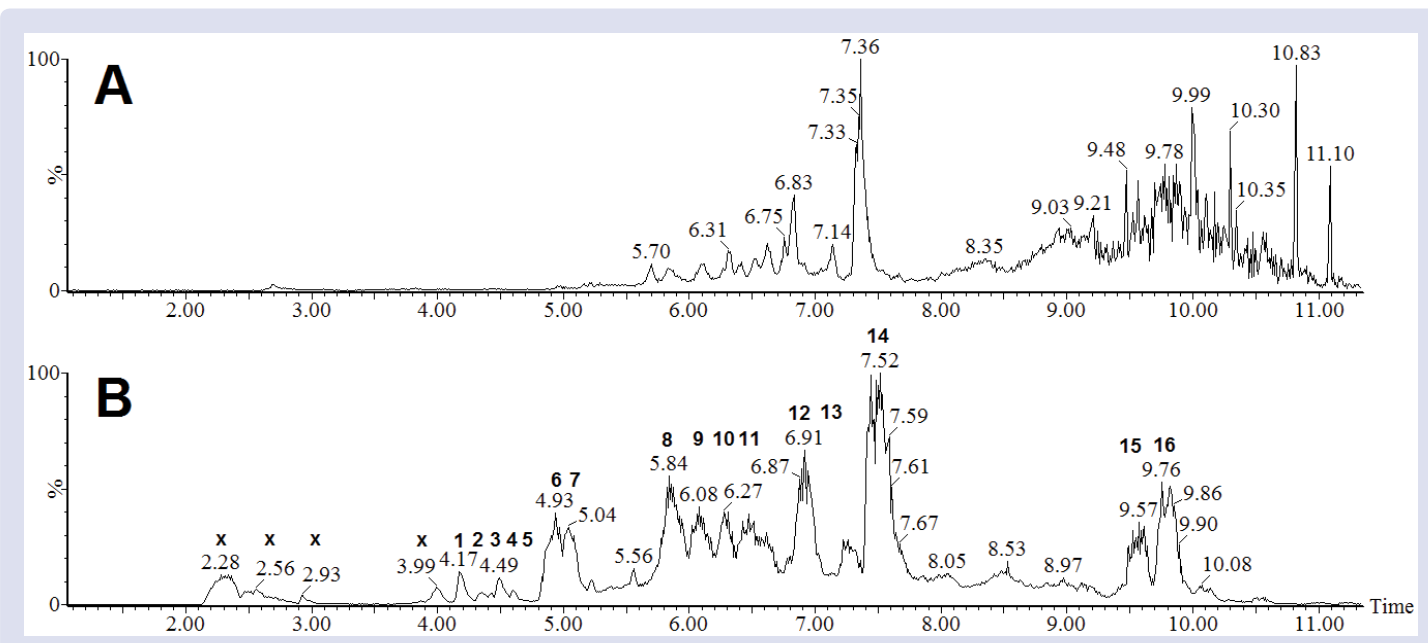

Figure 3: Chromatograms of the UPLC-ESI-QTof MS extracts, LHE (A) and LAE (B), of M. charantia obtained in positive ionization mode. Peaks with " $\mathrm{X}$ " are impurities. 
Table 2: Chemical identification of compounds of the hydroalcholic (FEC) and acetone (FAC) extracts from the leaves of Momordica charantia L. “Melãode-são-caetano".

\begin{tabular}{|c|c|c|c|c|c|c|c|c|c|c|}
\hline Peak & $\begin{array}{l}\text { Rt } \\
\min \end{array}$ & $\begin{array}{l}{[\mathrm{M}+\mathrm{H}]^{+} /} \\
{[\mathrm{M}+\mathrm{Na}]^{+}} \\
\text {Observed }\end{array}$ & $\begin{array}{c}{[\mathrm{M}+\mathrm{H}]^{+} /} \\
{[\mathrm{M}+\mathrm{Na}]^{+}} \\
\text {Calculated }\end{array}$ & $\begin{array}{c}\text { Product } \\
\text { Ions (MS/MS) }\end{array}$ & $\begin{array}{l}\text { Empirical } \\
\text { Formula }\end{array}$ & $\begin{array}{l}\text { Ppm } \\
\text { (error) }\end{array}$ & Putative Name & LHE & LAE & Ref \\
\hline 1 & 4.17 & 205.0974 & 205.0977 & $146.0581,130.0630$ & $\mathrm{C}_{11} \mathrm{H}_{13} \mathrm{~N}_{2} \mathrm{O}_{2}$ & -1.5 & Tryptophan & $\mathrm{x}$ & - & 57 \\
\hline 2 & 4.35 & 465.1047 & 465.1033 & 303.0482 & $\mathrm{C}_{21} \mathrm{H}_{21} \mathrm{O}_{12}$ & 3.0 & Quercetin-O-hexoside & $\mathrm{x}$ & - & 58 \\
\hline 3 & 4.49 & 465.1031 & 465.1033 & 303.0475 & $\mathrm{C}_{21} \mathrm{H}_{21} \mathrm{O}_{12}$ & -0.4 & Quercetin-O-hexoside & $\mathrm{x}$ & $\mathrm{x}$ & 58 \\
\hline 4 & 4.52 & 449.1071 & 449.1084 & 303.0463 & $\mathrm{C}_{21} \mathrm{H}_{21} \mathrm{O}_{11}$ & -2.9 & Quercetin-O-rhamnoside & $\mathrm{x}$ & $\mathrm{x}$ & 58 \\
\hline 5 & 4.60 & 449.1101 & 449.1084 & 287.0553 & $\mathrm{C}_{21} \mathrm{H}_{21} \mathrm{O}_{11}$ & 3.8 & Kaempferol-O-hexoside & $\mathrm{x}$ & $\mathrm{x}$ & 58 \\
\hline 6 & 4.93 & 805.5035 & 805.5043 & $\begin{array}{c}787.4910,614.4079 \\
175.1103\end{array}$ & $\mathrm{C}_{52} \mathrm{H}_{69} \mathrm{O}_{7}$ & -1.0 & Unknown & $\mathrm{x}$ & - & - \\
\hline 7 & 5.03 & 769.4990 & 769.4985 & $333.1419,175.1169$ & $\mathrm{C}_{56} \mathrm{H}_{65} \mathrm{O}_{2}$ & 0.6 & Unknown & $\mathrm{x}$ & - & - \\
\hline 8 & 5.84 & 437.3416 & 437.3420 & $\begin{array}{l}419.3302,409.3449 \\
391.3350,109.0965\end{array}$ & $\mathrm{C}_{30} \mathrm{H}_{45} \mathrm{O}_{2}$ & 0.9 & $\begin{array}{c}\text { Hydroxycucurbitatetraenal } \\
\text { isomer }\end{array}$ & $\mathrm{x}$ & $\mathrm{x}$ & 59 \\
\hline 9 & 6.08 & 437.3431 & 437.3420 & $\begin{array}{l}419.3287,409.3463 \\
391.3387,109.1014\end{array}$ & $\mathrm{C}_{30} \mathrm{H}_{45} \mathrm{O}_{2}$ & 2.5 & $\begin{array}{c}\text { Hydroxycucurbitatetraenal } \\
\text { isomer }\end{array}$ & $\mathrm{x}$ & $\mathrm{x}$ & 59 \\
\hline 10 & 6.27 & 437.3434 & 437.3420 & $\begin{array}{l}419.3312,409.3437 \\
391.3375,109.1018\end{array}$ & $\mathrm{C}_{30} \mathrm{H}_{45} \mathrm{O}_{2}$ & 3.2 & $\begin{array}{c}\text { Hydroxycucurbitatetraenal } \\
\text { isomer }\end{array}$ & $\mathrm{x}$ & $\mathrm{x}$ & 59 \\
\hline 11 & 6.47 & 629.3694 & 629.3690 & $\begin{array}{c}437.3415,419.3294 \\
409.3463,391.3355 \\
109.1007\end{array}$ & $\mathrm{C}_{36} \mathrm{H}_{53} \mathrm{O}_{9}$ & 0.6 & $\begin{array}{l}\text { Oleanane- triterpenoid } \\
\text { saponin }\end{array}$ & $\mathrm{x}$ & $\mathrm{x}$ & 60 \\
\hline 12 & 6.91 & 455.3530 & 455.3525 & $\begin{array}{c}437.3390,419.3274 \\
409.3472,391.3347 \\
109.1015\end{array}$ & $\mathrm{C}_{30} \mathrm{H}_{47} \mathrm{O}_{3}$ & 1.1 & $\begin{array}{l}\text { Epoxycurcubitatrienediol } \\
\text { isomer }\end{array}$ & $\mathrm{x}$ & $\mathrm{x}$ & 22,61 \\
\hline 13 & 7.26 & 581.3455 & 581.3454 & $\begin{array}{c}541.3593,523.3412, \\
495.3454,437.3396 \\
409.3545,391.3342 \\
109.0979\end{array}$ & $\mathrm{C}_{33} \mathrm{H}_{50} \mathrm{O}_{7} \mathrm{Na}$ & 0.3 & $\begin{array}{l}\text { 3-[(5-formyl-7 } \beta, 25 \text {-dihy- } \\
\text { droxymethoxycucurbita-5,- } \\
\text { 23-dien-3-yl)oxy]-3-oxopro- } \\
\text { panoic acid isomer }\end{array}$ & $\mathrm{x}$ & $\mathrm{x}$ & 62 \\
\hline 14 & 7.52 & 455.3527 & 455.3525 & $\begin{array}{c}437.3463,419.3361 \\
409.3446,391.3396 \\
109.1000\end{array}$ & $\mathrm{C}_{30} \mathrm{H}_{47} \mathrm{O}_{3}$ & 0.4 & $\begin{array}{l}\text { Epoxycurcubitatrienediol } \\
\text { isomer }\end{array}$ & $\mathrm{x}$ & $\mathrm{x}$ & 59,63 \\
\hline 15 & 9.57 & 477.3376 & 477.3376 & $\begin{array}{l}437.3398,419.3287 \\
391.3346,109.0984\end{array}$ & $\mathrm{C}_{32} \mathrm{H}_{45} \mathrm{O}_{3}$ & 1.5 & Unknown & $\mathrm{x}$ & $\mathrm{x}$ & - \\
\hline 16 & 9.76 & 525.3571 & 525.3580 & $\begin{array}{c}493.3336,437.3434 \\
419.3293,391.3380 \\
109.1009\end{array}$ & $\mathrm{C}_{33} \mathrm{H}_{49} \mathrm{O}_{5}$ & -1.7 & Unknown & $\mathrm{x}$ & $\mathrm{x}$ & - \\
\hline
\end{tabular}

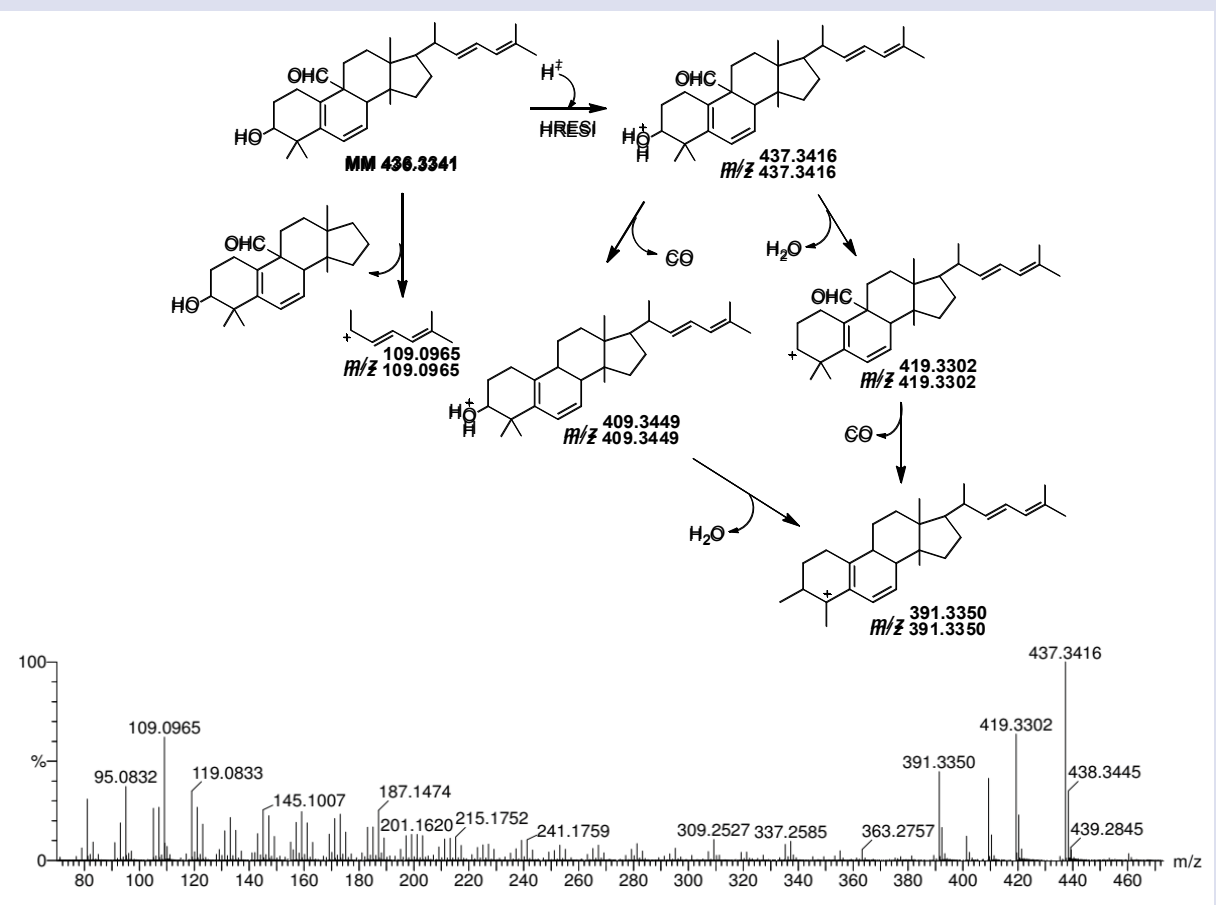

Figure 4: Fragmentation patterns of the 3ß-hydroxycucurbita-5 (10), 6, 22 (E), 24-tetraen-19-al. 


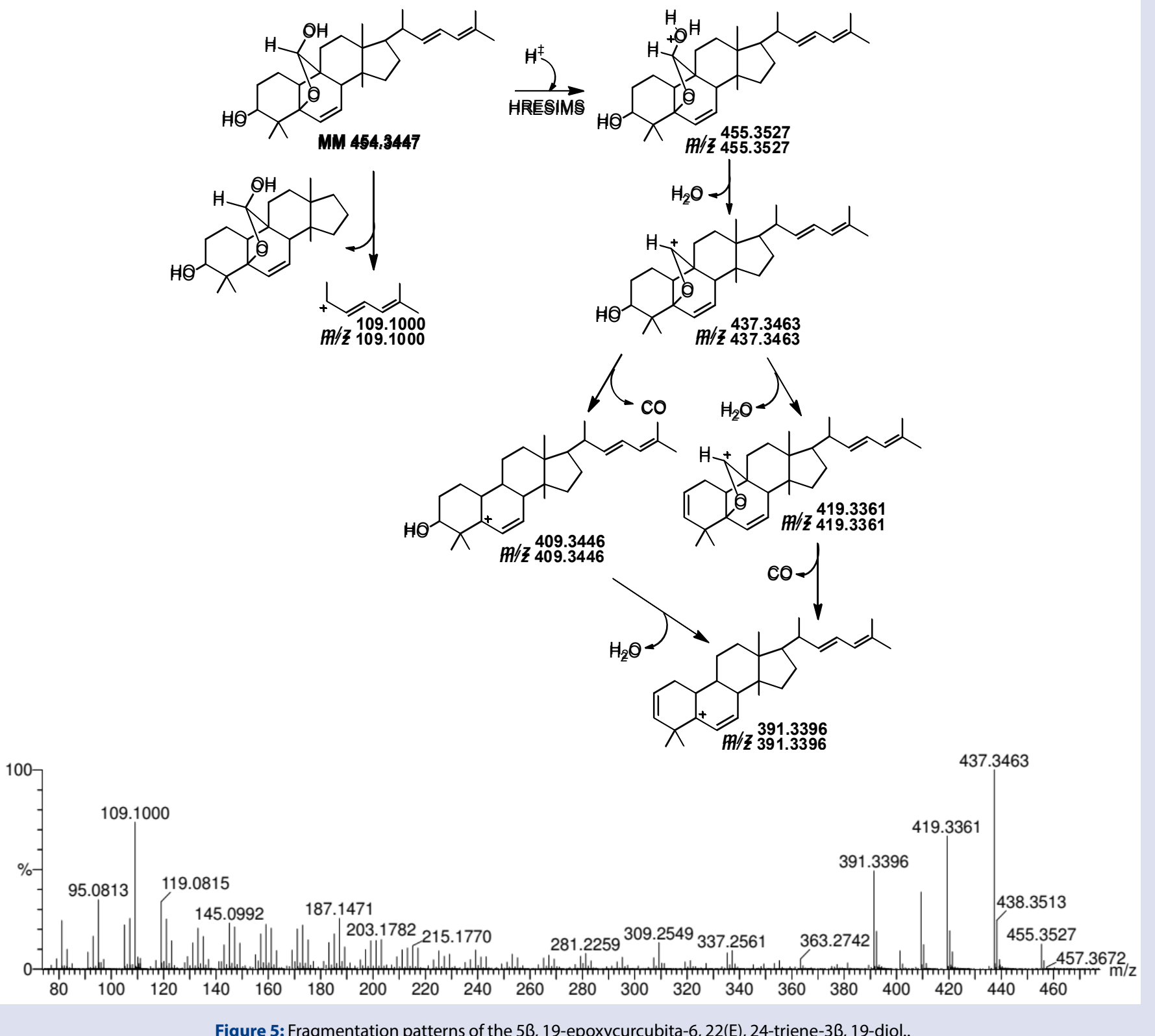

\section{Literature survey of ethnomedicinal uses and biological} or pharmacological compounds identified or isolated from M. charantia.

We present the ethnomedicinal uses reported from the northeastern region of Brazil (Table 3 ) and then made a summary of phytochemicals reportedly identified or isolated from $M$. charantia and verified in this present local variety, with the view of presenting plausible role for these metabolites in the potential therapeutic effects of this plant.

Literature survey of the ethnomedicinal uses in the northeast region of Brazil of $M$. charantia and its identified metabolites revealed some interesting findings. In spite of the widespread uses of this important food and medicinal plants, there are still lack of rigorous preclinical and clinical studies, particularly for many of its ethnomedicinal claims. In fact, there is no clinically supported medicinal uses. ${ }^{68}$ It is also surprising that some of the biological activities reported are anecdotal due to poor experimental designs, among others. For example, some studies related its biological activities using solutions made from the plants parts without stating the concentrations or dose used, the use of solvents other than those used reported in the ethnomedicinal uses, the parts used in the studies and sometimes the route of administration of the extracts. The most pre-clinically substantiated activities of $M$. charantia are its anti-diabetic and anti-neoplastic activities ${ }^{16,20,26,27,69,70}$.

In the present study, we demonstrated the antibacterial and antifungal activities of the leaves extracts of $M$. charantia against clinically important bacterial and fungal strains. Similar reports have been observed in the literature ${ }^{28-30,37,106}$. In order to be able to give plausible explanation as to the activity observed as well as to standardized the extracts, we performed phytochemical studies on the two extracts studied in the present work. Among the structures identified by UPLC in LHE and LAE extracts of $M$. charantia, a number of compounds derived from flavonoids and many of which have been shown to possess antimicrobial activities were identified in LHE. However, some of these 

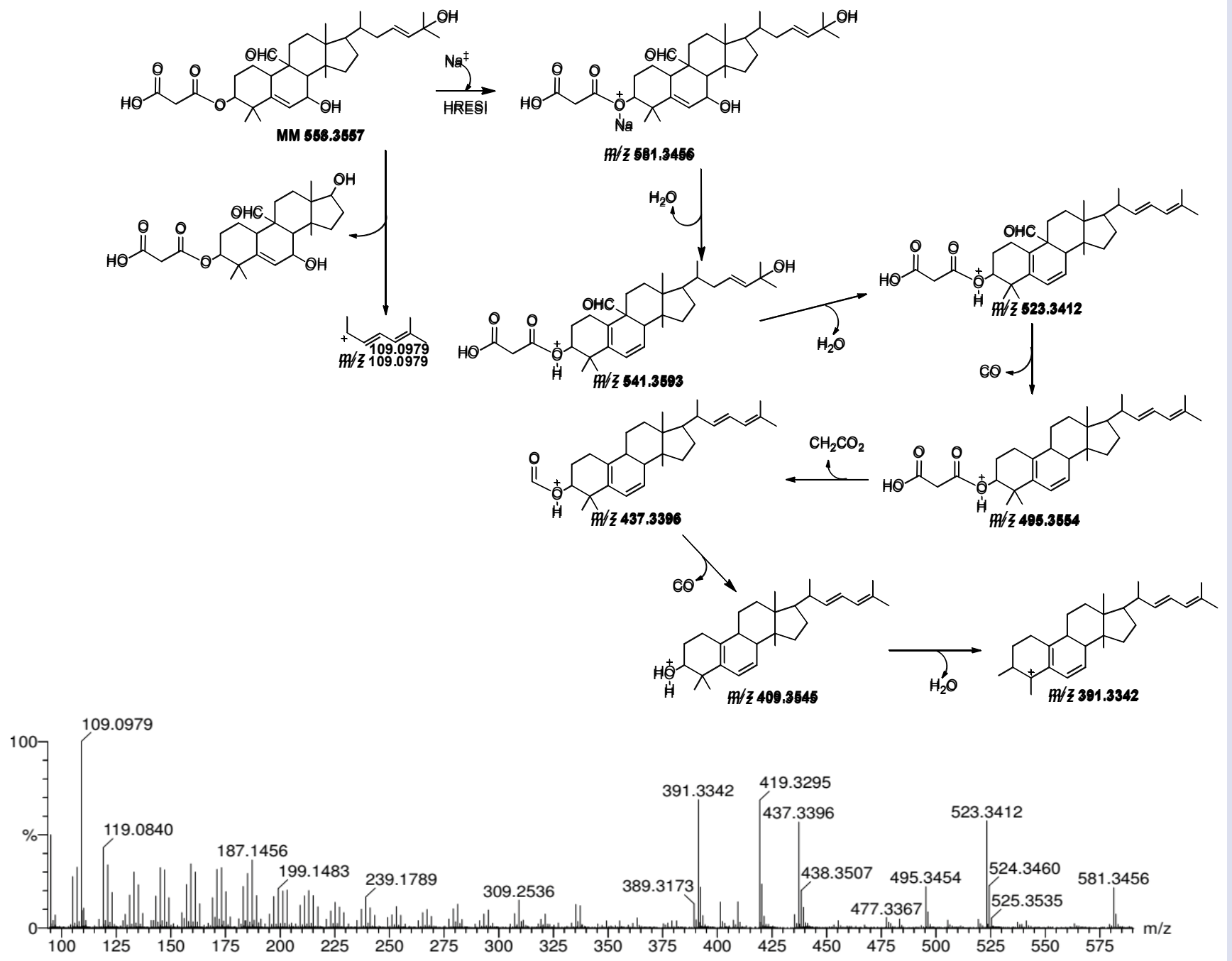

Figure 6: Fragmentation patterns of the 3-[(5-formyl-7ß, 25-dihydroxymethoxycucurbita-5, 23-dien-3-yl) oxy]-3-oxopropanoic acid.

constituents do not appear in LAE extract, which presented better antimicrobial and antifungal activity, suggesting that there are other metabolites, that were not identified in the present work and, which may contribute, at least in part, to the antibacterial and antifungal activities observed.

To the best of our knowledge, there are no sufficient chemical and biological studies to indicate the substances responsible for antibacterial or antifungal activity of $M$. charantia.

These results further demonstrate therapeutic potential of $M$. charantia extracts and calls for further biological and pharmacological prospecting of this important plant. There is need for in vivo antimicrobial assays to confirm the potential antimicrobial activity of the plant and its phytochemical constituents that are yet to be subjected to biological/pharmacological studies. In fact, most of its important phytochemical compounds are without biological or pharmacological studies. Majority of studies on its isolates are focused on antidiabetic and anti-cancer activities. In addition, there is lack of studies on many of its ethnomedicinal uses. Furthermore, there is need to carry out mechanistic studies to determine how M. charantia and or its constituents afford the antimicrobial action observed here as in many studies.

\section{CONCLUSION}

The hydroethanolic extract (LHE) and acetone (LAE) from $M$. charantia L. showed different patterns of antimicrobial action against Gram-positive bacteria ( $S$. aureus and S. epidermidis) and on yeast (C. albicans), which are believed to be due to the differences in the composition of extracts as shown by the UPLC analysis of constituents. The study is a pioneer in the association between antimicrobial activity of different Brazilian bitter gourd extracts and its chemical constituents. Nevertheless, studies that will evaluate the compounds alone and in association, as well as those investigating their mechanisms of action are needed to elucidate this pharmacological effect.

\section{ACKNOWLEDGEMENT}

The authors would like to thank the Organization of American States (OAS) for conceding study fellowship grant to the first author, Grupo de Universidades Brasileiras de Coimbra (GCUB), Coordenação de Aperfeiçoamento de Pessoal de Nível Superior (CAPES), a Fundação Cearense de Apoio ao Desenvolvimento Científico e Tecnológico (FUNCAP) for financial assistance, and to the Researchers of the Multi-user Laboratory of Chemistry of Natural Products of EMBRAPA AGROINDÚSTRIA TROPICAL. 
Table 3: Summary of ethnomedicinal uses, chemical compounds identified, and activities reported in the literature that corresponds to $M$. charantia ethnomedicinal uses in the northeastern region of Brazil.

\begin{tabular}{|c|c|c|c|}
\hline Ethnomedicinal uses & $\begin{array}{c}\text { Confirmed biological/ } \\
\text { pharmacological activities }\end{array}$ & $\begin{array}{l}\text { Chemical compounds or extracts } \\
\text { with activity }\end{array}$ & References \\
\hline $\begin{array}{l}\text { Indication in skin treatments wound } \\
\text { healing. }\end{array}$ & Wound healing: various model & Fruit powder, extracts & $26,71-77$ \\
\hline $\begin{array}{c}\text { Antiseptic (skin infections, mycoses) } \\
\text { and antimicrobial }\end{array}$ & Antibacterial and antifungal activities & $\begin{array}{l}\text { Quercetin-O-hexoside isomers, } \\
\text { kaempferol, tannins, flavonoids and } \\
\text { alkaloids, various crude extracts }\end{array}$ & $29,78-90$ \\
\hline Antiviral & $\begin{array}{l}\text { antiviral activity (inhibit HRV2 } \\
\text { replication) }\end{array}$ & Quercetin-7-Glucoside & 91,92 \\
\hline Scabies, vermifuge, anthelminthic & Anti-helminthic activity & Crude extracts & 93 \\
\hline Tumor and benign breast neoplasm & $\begin{array}{l}\text { Antineoplastic and anti-tumor, } \\
\text { anti-hepatocellular carcinoma; renal } \\
\text { carcinoma cells in-vitro anticancer, } \\
\text { malignant melanoma, cytotoxicity } \\
\text { against chondrosarcoma SW } 1353 \\
\text { cell line; modulates the progression of } \\
\text { androgen-independent human prostate } \\
\text { cancer cell line. }\end{array}$ & $\begin{array}{l}\text { MAP30, Cucurbitacins (Cucurbitacin E } \\
\text { glucoside, and Cucurbitacin I glucoside, } \\
\text { cucurbitacines A, B, D, E), Kuguacin } \\
\text { J and Cucurbitane-type triterpenoids } \\
\text { (charantosides, momordicosides, } \\
\text { karavilosides, karavilagenin D) and } \\
\text { quercetin }\end{array}$ & $19,20,26,27,45,47,49-54,56,70,94-105$ \\
\hline Anti-diabetic & $\begin{array}{l}\text { Antidiabetic activity, stimulatory effect } \\
\text { on insulin secretion and various others, } \\
\text { including clinical trials(too numerous } \\
\text { to mention all) }\end{array}$ & $\begin{array}{l}\text { Different extracts of M. charantia, } \\
\text { Kuguacin (The Kuguacin R and } \\
\text { Kuguacin II, 3 } \beta, 7 \beta, 25 \text {-trihydroxycucur } \\
\text { bita-5,23(E)-diene-19-al, momordicine } \\
\text { I, Momordicosides L, charantoside VII }\end{array}$ & $15,17,26,27,61,69,106-108$ \\
\hline Internal and external inflammation & $\begin{array}{l}\text { Pre-clinical anti-inflammatory } \\
\text { activities, and in patients with primary } \\
\text { knee osteoarthritis }\end{array}$ & $\begin{array}{l}\text { Cucurbitacins, quercetin, kaempferol, } \\
\text { and plant crude extracts }\end{array}$ & $17,20,71,105,109-119$ \\
\hline Contraceptive & Antiestrogen activity & $\begin{array}{c}\text { Triterpenoid, Kaempferol Cucurbita-6, } \\
22 \text { (E), 24-trien-3 } \beta \text {-ol-19,5 } \beta \text {-olide, } \\
\text { crude extract }\end{array}$ & 59,120 \\
\hline Immunostimulanting & Immunomodulatory activity & Polysaccharides from $M$. charantia & 121 \\
\hline Antimalarial & $\begin{array}{l}\text { In vitro (positive) and in vivo (no } \\
\text { effect) anti-plasmodium activity }\end{array}$ & Crude extracts & 122,123 \\
\hline Anti-diarrheal & In vivo anti-diarrheal activity & Crude aqueous extract & 124 \\
\hline $\begin{array}{l}\text { Indication in skin treatments: eczema, } \\
\text { acne, scabies, hemorrhoid, and } \\
\text { furuncles, carbuncle }\end{array}$ & No report & No report & \\
\hline Gastroenteritis & No reports & No reports & \\
\hline Colitis & No reports & No reports & \\
\hline Gynecological inflammation & No report & No report & \\
\hline Vaginal discharge & No report & No report & \\
\hline Hemostatic & No reports & No reports & \\
\hline Nasal congestion & No reports & No reports & \\
\hline
\end{tabular}

\section{REFERENCES}

1. Carney J. Navegando Contra a Corriente: o papel dos escravos e da flora africana na botânica do período colonial. África Rev Estud Africanos. 2001;22(23):25-47.

2. Duke JA. Handbook of Medicinal Herbs. 2nd ed. Boca Raton: CRC Press; 2002.

3. Matos FJ de A. Medicinal Plants - Guide for Selection and Employment of Plants Used in Phytotherapy in the Northeast of Brazil. Plantas Medicinais Guia de Seleção e Emprego de Plantas Usadas Em Fitoterapia No Nordeste Do Brasil. 3rd ed. Ceará: Ediçoes UFC; 2007.

4. NOBRE GS. Studies on the Descriptive Collection of Plants of the Ceará Capitania Estudos Sobre a Coleção Descritiva Das Plantas Da Capitania Do Ceará. Fortaleza: Gráfica Editorial Cearense Ltda.; 1984.

5. Biblioteca Nacional. OS MANUSCRITOS DO BOTÂNICO FREIRE ALEMÃO Catálogo e Transcrição. Vol 81. (Damasceno D, Cunha W da, eds.). Brasilia, Brazil: Biblioteca Nacional, DIVISÃO DE PUBLICAÇÕES E DIVULGAÇÃO; 1961.

6. Matos FJA (Francisco J de A, Rocha FD da. O Formulário Fitoterápico Do Professor Dias Da Rocha : Informacões Sobre o Emprego Na Medicina Caseira de Plantas Do Nordeste, Especialmente Do Ceará. UFC Edições; 1997. https:// books.google.com.br/books/about/O_formulário_fitoterápico_do_professor. html?id=T9JfAAAAMAAJ\&redir_esc=y. Accessed June 24, 2019.

7. Braga R. Plantas Do Nordeste : Especialmente Do Ceará / Renato Braga. - IHGB - Instituto Histórico Geográfico Brasileiro. 5th ed. Fortaleza: Escola Superior de Agricultura de Mossoró:; 2001. https://ihgb.org.br/pesquisa/biblioteca/ item/14062-plantas-do-nordeste-especialmente-do-ceará-renato-braga.html. Accessed June 24, 2019

8. Matos FJA (Francisco J de A. Plantas Da Medicina Popular Do Nordeste Propriedades Atribuídas e Confirmadas. Fortaleza: UFC Edicões; 1999. https://books.google.com.br/books/about/Plantas_da_medicina_popular_do_ nordeste.html?id=f5PiNQAACAAJ\&redir_esc=y. Accessed June 24, 2019.

9. Magalhães K do N, GuarnizWAS, Sá KM, et al. Medicinal plants of the Caatinga, northeastern Brazil: Ethnopharmacopeia (1980-1990) of the late professor Francisco José de Abreu Matos. J Ethnopharmacol. 2019;237:314-53.

10. Olasehinde $\mathrm{GI}$, Ojurongbe $\mathrm{O}$, Adeyeba $\mathrm{AO}$, et al. In vitro studies on the sensitivity pattern of Plasmodium falciparum to anti-malarial drugs and local herbal extracts. Malar J. 2014;13(1):63.

11. Santos KKA, Matias EFF, Sobral-Souza CE, et al. Trypanocide, cytotoxic, and antifungal activities of Momordica charantia. Pharm Biol. 2012;50(2):162-6.

12. Wu S-B, Yue G, To M-H, Keller A, Lau C, Kennelly E. Transport in Caco-2 Cell Monolayers of Antidiabetic Cucurbitane Triterpenoids from Momordica charantia Fruits. Planta Med. 2014;80(11):907-11.

13. Chen JC, Lau CBS, Chan JYW, et al. The antigluconeogenic activity of cucurbitacins from Momordica charantia. Planta Med. 2015;81(4):327-32.

14. Keller AC, Ma J, Kavalier A, He K, Brillantes AMB, Kennelly EJ. Saponins from the traditional medicinal plant Momordica charantia stimulate insulin secretion in vitro. Phytomedicine. 2011. 
15. Jiang B, Ji M, Liu W, et al. Antidiabetic activities of a cucurbitane-type triterpenoid compound from Momordica charantia in alloxan-induced diabetic mice. Mol Med Rep. 2016;14(5):4865-72.

16. May M, Schindler C. Clinically and pharmacologically relevant interactions of antidiabetic drugs. Ther Adv Endocrinol Metab. 2016;7(2):69-83.

17. Shivanagoudra SR, Perera WH, Perez JL, et al. Cucurbitane-type compounds from Momordica charantia: Isolation, in vitro antidiabetic, anti-inflammatory activities and in silico modeling approaches. Bioorg Chem. 2019;87:31-42.

18. Gupta S, Raychaudhuri B, Banerjee S, Das B, Mukhopadhaya S, Datta SC Momordicatin purified from fruits of Momordica charantia is effective to act as a potent antileishmania agent. Parasitol Int. 2010;59(2):192-7.

19. Lee-Huang S, Huangi PL, Huang4 PL, Bourinbaiar AS, Chens H-C, Kungii $\mathrm{H}$-F. Inhibition of the Integrase of Human Immunodeficiency Virus (HIV) Type 1 by Anti-HIV Plant Proteins MAP30 and GAP31 (AIDS/Antiviral Target/DNA Integration/Antiviral Agents). Vol 92.; 1995. https://www.ncbi.nlm.nih.gov/pmc/ articles/PMC41058/pdf/pnas01497-0295.pdf. Accessed June 15, 2019.

20. Dandawate PR, Subramaniam D, Padhye SB, Anant S. Bitter melon: a panacea for inflammation and cancer. Chin J Nat Med. 2016;14(2):81-100.

21. Nhiem NX, Kiem P Van, Minh C Van, et al. \&alpha;-Glucosidase Inhibition Properties of Cucurbitane-Type Triterpene Glycosides from the Fruits of Momordica charantia. Chem Pharm Bull (Tokyo). 2010;58(5):720-4.

22. Pitchakarn $P$, Suzuki S, Ogawa $K$, et al. Kuguacin J, a triterpeniod from Momordica charantia leaf, modulates the progression of androgen-independent human prostate cancer cell line, PC3. Food Chem Toxicol. 2012.

23. Brasil - Ministério Da Saúde. Relação Nacional de Plantas Medicinais de Interesse Ao SUS. Brasília - DF; 2009. http://portal.saúde.gov.br/portal/arquivos/ pdf/RENISUS.pdf.

24. CEARÁ - SECRETARIA DA SAÚDE DO ESTADO. PORTARIA No 275/2012. Brazil: SECRETÁRIO DA SAÚDE DO ESTADO DO CEARÁ, GESTOR ESTADUAL DO SISTEMA ÚNICO DE SAÚDE NO CEARÁ-SUS/CE; 2012:75.

25. Anvisa. Formulário de Fitoterápicos da Farmacopéia Brasileira. Agencia Nac Vigil Sanitária. 2011:126. www.anvisa.gov.br. Accessed June 9, 2019.

26. Jia S, Shen M, Zhang F, Xie J. Recent advances in momordica charantia: Functional components and biological activities. Int J Mol Sci. 2017;18(12).

27. Grover JK, Yadav SP. Pharmacological actions and potential uses of Momordica charantia: A review. J Ethnopharmacol. 2004;93(1):123-32.

28. Abalaka ME, Onaolapo JA, Inabo HI, Olonitola OS. Antibacterial activity of chromatographically separated pure fractions of whole plant of momordica charantia L (Cucurbitaceae). Adv Environ Biol. 2010;4(3):509-14.

29. Costa JGM, Nascimento EMM, Campos AR, Rodrigues FFG. Antibacterial activity of Momordica charantia (Curcubitaceae) extracts and fractions. J Basic Clin Pharm. 2011;2(1):45-51. www.jbclinpharm.com. Accessed June 9, 2019.

30. Maia RR, Pereira M do SV, Higino JS, et al. Antimicrobial effect of extract momordica charantia linn isolated and in combination with antibiotics on resistant staphylococcus aureus. Efeito Antimicrobiano do Extrato de Momordica charantia Linn Isolado e em Associação Com Antibióticos Sobre Staphylo. Agropecuária Científica no Semi-Árido. 2008;4:12-7.

31. CLSI. Reference Method for Broth Dilution Antifungal Susceptibility Testing of Yeasts. Document; 2008. p. M27-A3.; 2008.

32. CLSI. Reference Method for Broth Dilution Antifungal Susceptibility Testing of Yeasts, M27. 4th ed. Wayne, Pennsylvania USA: Clinical and Laboratory Standards Institute; 2017. www.clsi.org. Accessed June 22, 2019.

33. Palomino J-C, Martin A, Camacho M, Guerra H, Swings J, Portaels F. Resazurin Microtiter Assay Plate: Simple and Inexpensive Method for Detection of Drug Resistance in Mycobacterium tuberculosis. Antimicrob Agents Chemother. 2002;46(8):2720-2.

34. Baron EJ, Peterson LR, Finegold SM, Inc U, Bayman P, Baker JL. Baily\&Scolts" Diagnostic Microbiology. 1994;9.

35. Yamaguchi N, Satoh-Yamaguchi K, Ono M. In vitro evaluation of antibacterial, anticollagenase, and antioxidant activities of hop components (Humulus lupulus) addressing acne vulgaris. Phytomedicine. 2009;16(4):369-76.

36. Aligiannis N, Kalpoutzakis E, Mitaku S, Chinou IB. Composition and antimicrobial activity of the essential oils of two origanum species. J Agric Food Chem. 2001;49(9):4168-70.

37. Arruda E, Ponzi C, Thompson I, et al. Antimicrobial activity of the Mormodica charantia L. extract. Rev Cir e Traumatol Buco Maxilo Facial. 2010;10(1):89-94.

38. Mahomoodally MF, Gurib-Fakim A, Subratty AH. Screening for alternative antibiotics: an investigation into the antimicrobial activities of medicinal food plants of Mauritius. J Food Sci. 2010;75(3):M173-7.

39. Yaldız G, Sekeroglu N, Kulak M, Demirkol G. Antimicrobial activity and agricultural properties of bitter melon (Momordica charantia L.) grown in northern parts of Turkey: a case study for adaptation. Nat Prod Res. 2015;29(6):543-5.

40. Mwambete KD. The in vitro antimicrobial activity of fruit and leaf crude extracts of Momordica charantia: a Tanzania medicinal plant. Afr Health Sci. 2009;9(1):34-9.
41. Gobbo-Neto L, Lopes NP. [Medicinal Plants: Factors that influence the Secundary Metabolites Contents] Plantas medicinais: fatores de influência no conteúdo de metabólitos secundários. Quim Nova. 2007;30(2):374-81.

42. Llorach R, Martínez-Sánchez A, Tomás-Barberán FA, Gil MI, Ferreres F. Characterisation of polyphenols and antioxidant properties of five lettuce varieties and escarole. Food Chem. 2008;108(3):1028-38.

43. Srivastava G, Jain R, Vyas N, Mehta A, Kachhwaha S, Kothari SL. Antimicrobial activity of the methanolic extract, fractions and isolated compounds from citrullus colocynthis (I.) schrad. Int J Pharma Bio Sci. 2013;4(3):825-33.

44. Mehta A, Srivastva G, Kachhwaha S, Sharma M, Kothari SL. Antimycobacterial activity of Citrullus colocynthis (L.) Schrad. against drug sensitive and drug resistant Mycobacterium tuberculosis and MOTT clinical isolates. J Ethnopharmacol. 2013;149(1):195-200.

45. Aeri V, Kaushik U, Mir S. Cucurbitacins - An insight into medicinal leads from nature. Pharmacogn Rev. 2015;9(17):12.

46. Recio MC, Andujar I, Rios JL. Anti-inflammatory agents from plants: progress and potential. Curr Med Chem. 2012;19(14):2088-103.

47. Jian CC, Ming HC, Rui LN, Cordel GA, Qiuz SX. Cucurbitacins and cucurbitane glycosides: Structures and biological activities. Nat Prod Rep. 2005;22(3):38699.

48. Sharifi-Rad M, Fokou PVT, Sharopov F, et al. Antiulcer agents: From plant extracts to phytochemicals in healing promotion. Molecules. 2018;23(7).

49. Henrich CJ, Thomas CL, Brooks AD, et al. Effects of cucurbitacins on cell morphology are associated with sensitization of renal carcinoma cells to TRAILinduced apoptosis. Apoptosis. 2012;17(1):79-89.

50. Abbas S, Vincourt J-B, Habib L, Netter P, Greige-Gerges H, Magdalou J. The cucurbitacins $E, D$ and I: investigation of their cytotoxicity toward human chondrosarcoma SW 1353 cell line and their biotransformation in man liver. Toxicol Lett. 2013;216(2-3):189-99.

51. Silva IT, Geller FC, Persich L, et al. Cytotoxic effects of natural and semisynthetic cucurbitacins on lung cancer cell line A549. Invest New Drugs. 2016;34(2):13948.

52. Hussain $H$, Green IR, Saleem M, Khattak KF, Irshad M, Ali M. Cucurbitacins as Anticancer Agents: A Patent Review. Recent Pat Anticancer Drug Discov. 2018;13.

53. Ríos JL, Escandell JM, Recio MC. New insights into the bioactivity of cucurbitacins. In: Studies in Natural Products Chemistry. 2005:429-69.

54. Ahmed MS, Halaweish FT. Cucurbitacins: potential candidates targeting mitogen-activated protein kinase pathway for treatment of melanoma. J Enzyme Inhib Med Chem. 2014;29(2):162-7.

55. Kaushik U, Aeri V, Mir SR. Cucurbitacins - An insight into medicinal leads from nature. Pharmacogn Rev. 2015;9(17):12-8.

56. Cai $Y$, Fang $X, \mathrm{He} \mathrm{C}$, et al. Cucurbitacins: A systematic review of the phytochemistry and anticancer activity. Am J Chin Med. 2015;43(7):1331-50.

57. Thiele B, Füllner K, Stein N, Oldiges M, Kuhn AJ, Hofmann D. Analysis of amino acids without derivatization in barley extracts by LC-MS-MS. Anal Bioanal Chem. 2008;391(7):2663-72.

58. Svobodova B, Barros L, Calhelha RC, et al. Bioactive properties and phenolic profile of Momordica charantia L. medicinal plant growing wild in Trinidad and Tobago. Ind Crops Prod. 2017;95:365-73.

59. Hsu C, Hsieh C-L, Kuo Y-H, Huang C. Isolation and Identification of CucurbitaneType Triterpenoids with Partial Agonist/Antagonist Potential for Estrogen Receptors from Momordica charantia. J Agric Food Chem. 2011;59(9):4553-61.

60. Fan R, Cheng R-R, Zhu H-T, et al. Two New Oleanane-type Triterpenoids from Methanolyzed Saponins of Momordica cochinchinensis. Nat Prod Commun. 2019;11(6):1934578X1601100.

61. Chen J-C, Liu W-Q, Lu L, et al. Kuguacins F-S, cucurbitane triterpenoids from Momordica charantia. Phytochemistry. 2009;70(1):133-40.

62. Tuan NQ, Lee DH, Oh J, et al. Inhibition of Proliferation of Vascular Smooth Muscle Cells by Cucurbitanes from Momordica charantia. J Nat Prod. 2017.

63. Wang X, Sun W, Cao J, Qu H, Bi X, Zhao Y. Structures of New Triterpenoids and Cytotoxicity Activities of the Isolated Major Compounds from the Fruit of Momordica charantia L. J Agric Food Chem. 2012;60(15):3927-33.

64. Yasir M, Sultana B, Nigam PS, Owusu-Apenten R. Antioxidant and genoprotective activity of selected cucurbitaceae seed extracts and LC-ESIMS/ MS identification of phenolic components. Food Chem. 2016;199:307-13.

65. Madala NE, Piater L, Dubery I, Steenkamp P. Distribution patterns of flavonoids from three Momordica species by ultra-high performance liquid chromatography quadrupole time of flight mass spectrometry: a metabolomic profiling approach. Rev Bras Farmacogn. 2016;26(4):507-13.

66. Chen Y, Yu H, Wu H, et al. Characterization and Quantification by LC-MS/ MS of the Chemical Components of the Heating Products of the Flavonoids Extract in Pollen Typhae for Transformation Rule Exploration. Molecules. 2015;20(10):18352-66. 
67. Chang C-I, Chen C-R, Liao Y-W, Cheng H-L, Chen Y-C, Chou C-H. CucurbitaneType Triterpenoids from Momordica c harantia. J Nat Prod. 2006;69(8):1168-71.

68. WHO. Selected Medicinal Plants Vol. 4. Essent Med Heal Prod Inf Portal A World Heal Organ Resour. 2005;4:381-99.

69. May M, Schindler C. Clinically and pharmacologically relevant interactions of antidiabetic drugs. Ther Adv Endocrinol Metab. 2016;7(2):69-83.

70. Santos HM dos, Oliveira DF, Carvalho DA de, et al. Evaluation of native and exotic Brazilian plants for anticancer activity. J Nat Med. 2010;64(2):231-8.

71. Hsu C, Tsai T-H, Li Y-Y, Wu W-H, Huang C-J, Tsai P-J. Wild bitter melon (Momordica charantia Linn. var. abbreviata Ser.) extract and its bioactive components suppress Propionibacterium acnes-induced inflammation. Food Chem. 2012;135(3):976-84.

72. Prasad V, Jain V, Girish D, Dorle AK. Wound-healing property of Momordica charantia L. fruit powder. J Herb Pharmacother. 2006;6(3-4):105-15.

73. Hussan F, Teoh SL, Muhamad N, Mazlan M, Latiff AA. Momordica charantia ointment accelerates diabetic wound healing and enhances transforming growth factor- $\beta$ expression. J Wound Care. 2014;23(8):400-7.

74. İlhan M, Bolat IE, Süntar I, et al. Topical application of olive oil macerate of Momordica charantia L. promotes healing of excisional and incisional wounds in rat buccal mucosa. Arch Oral Biol. 2015;60(12):1708-13.

75. Teoh SL, Latiff AA, Das S. The effect of topical extract of Momordica charantia (bitter gourd) on wound healing in nondiabetic rats and in rats with diabetes induced by streptozotocin. Clin Exp Dermatol. 2009;34(7):815-22.

76. Pereira LOM, Vilegas $W$, Tangerina MMP, et al. Lafoensia pacari A. St.-Hil.: Wound healing activity and mechanism of action of standardized hydroethanolic leaves extract. J Ethnopharmacol. 2018;219:337-50.

77. Działo M, Mierziak J, Korzun U, Preisner M, Szopa J, Kulma A. The Potential of Plant Phenolics in Prevention and Therapy of Skin Disorders. Int J Mol Sci. 2016;17(2):160.

78. Lee J-H, Park J-H, Cho HS, Joo SW, Cho MH, Lee J. Anti-biofilm activities of quercetin and tannic acid against Staphylococcus aureus. Biofouling. 2013;29(5):491-9

79. Faria RX, Souza ALA, Lima B, et al. Plants of Brazilian restingas with tripanocide activity against Trypanosoma cruzi strains. J Bioenerg Biomembr. 2017;49(6):473-83

80. Anusuya S, Gromiha MM. Quercetin derivatives as non-nucleoside inhibitors for dengue polymerase: molecular docking, molecular dynamics simulation and binding free energy calculation. J Biomol Struct Dyn. 2017;35(13):2895909.

81. Chen $\mathrm{H}$, Ouyang $\mathrm{K}$, Jiang $\mathrm{Y}$, et al. Constituent analysis of the ethanol extracts of Chimonanthus nitens Oliv. leaves and their inhibitory effect on $\alpha$-glucosidase activity. Int J Biol Macromol. 2017;98:829-36

82. Santos UP, Campos JF, Torquato HF V, et al. Antioxidant, antimicrobial and cytotoxic properties as well as the phenolic content of the extract from Hancornia speciosa Gomes. Agbor G, ed. PLoS One. 2016;11(12):e0167531.

83. Li M, Xu Z. Quercetin in a lotus leaves extract may be responsible for antibacterial activity. Arch Pharm Res. 2008;31(5):640-4.

84. Ledoux A, St-Gelais A, Cieckiewicz E, et al. Antimalarial Activities of Alkyl Cyclohexenone Derivatives Isolated from the Leaves of Poupartia borbonica. J Nat Prod. 2017;80(6):1750-7.

85. Pereira AMS, Hernandes C, Pereira SIV, et al. Evaluation of anticandidal and antioxidant activities of phenolic compounds from Pyrostegia venusta (Ker Gawl.) Miers. Chem Biol Interact. 2014;224:136-41.

86. da Silva ER, Maquiaveli C do C, Magalhães PP. The leishmanicidal flavonols quercetin and quercitrin target Leishmania (Leishmania) amazonensis arginase. Exp Parasitol. 2012;130(3):183-8.

87. Galochkina A V., Anikin VB, Babkin VA, Ostrouhova LA, Zarubaev VV. Virusinhibiting activity of dihydroquercetin, a flavonoid from Larix sibirica, against coxsackievirus B4 in a model of viral pancreatitis. Arch Virol. 2016;161(4):92938.

88. Golea L, Benkhaled M, Lavaud C, Long C, Haba H. Phytochemical components and biological activities of Silene arenarioides Desf. Nat Prod Res. 2017;31(23):2801-05

89. Harasstani O, Tham C, Israf D, Harasstani OA, Tham CL, Israf DA. Kaempferol and Chrysin Synergies to Improve Septic Mice Survival. Molecules. 2017;22(1):92.

90. Panlilio BG, Macabeo APG, Knorn M, et al. A lanostane aldehyde from Momordica charantia. Phytochem Lett. 2012;5(3):682-4.

91. Vrba J, Kren V, Vacek J, Papouskova B, Ulrichova J. Quercetin, quercetin glycosides and taxifolin differ in their ability to induce AhR activation and cyp1a1 expression in HepG2 cells. Phyther Res. 2012;26(11):1746-52.

92. Song JH, Park KS, Kwon DH, Choi HJ. Anti-Human Rhinovirus 2 Activity and Mode of Action of Quercetin-7-Glucoside from Lagerstroemia speciosa. J Med Food. 2013;16(4):274-79.
93. Poolperm S, Jiraungkoorskul W. An update review on the anthelmintic activity of bitter gourd, Momordica charantia. Pharmacogn Rev. 2017;11(21):31-4.

94. Aljohi A, Matou-Nasri S, Liu D, Al-Khafaji N, Slevin M, Ahmed N. Momordica charantia extracts protect against inhibition of endothelial angiogenesis by advanced glycation endproducts in vitro. Food Funct. 2018;9(11):5728-39.

95. Lee-Huang S, Huang PL, Sun Y, et al. Inhibition of MDA-MB-231 human breast tumor xenografts and HER2 expression by anti-tumor agents GAP31 and MAP30. Anticancer Res. 2000;20(2 A):653-59.

96. Ayyad S-EN, Abdel-Lateff A, Alarif WM, Patacchioli FR, Badria FA, Ezmirly ST. In vitro and in vivo study of cucurbitacins-type triterpene glucoside from Citrullus colocynthis growing in Saudi Arabia against hepatocellular carcinoma. Environ Toxicol Pharmacol. 2012;33(2):245-51.

97. Wang W-D, Liu Y, Su Y, et al. ANTITUMOR AND APOPTOTIC EFFECTS OF CUCURBITACIN A IN A-549 LUNG CARCINOMA CELLS IS MEDIATED VIA G2/M CELL CYCLE ARREST AND M-TOR/PI3K/AKT SIGNALLING PATHWAY. African J Tradit Complement Altern Med AJTCAM. 2017;14(2):75-82.

98. Chen J-C, Lau C, Chan J, et al. The Antigluconeogenic Activity of Cucurbitacins from Momordica charantia. Planta Med. 2015;81(04):327-32.

99. Souza PO de, Bianchi SE, Figueiró F, et al. Anticancer activity of flavonoids isolated from Achyrocline satureioides in gliomas cell lines. Toxicol Vitr. 2018;51:23-33.

100. Forni $C$, Braglia R, Lentini $A$, et al. Role of transglutaminase 2 in quercetininduced differentiation of B16-F10 murine melanoma cells. Amino Acids. 2009;36(4):731-8

101. Shi Z-H, Li N-G, Tang Y-P, et al. Biological Evaluation and SAR Analysis of O -Methylated Analogs of Quercetin as Inhibitors of Cancer Cell Proliferation. Drug Dev Res.

102. Massi A, Bortolini O, Ragno D, et al. Research Progress in the Modification of Quercetin Leading to Anticancer Agents. Molecules. 2017;22(8):1270.

103. Boykin C, Zhang G, Chen Y-H, et al. Cucurbitacin Ila: a novel class of anticancer drug inducing non-reversible actin aggregation and inhibiting survivin independent of JAK2/STAT3 phosphorylation. Br J Cancer. 2011;104(5):781-9.

104. Zhao GT, Liu JQ, Deng YY, et al. Cucurbitane-type triterpenoids from the stems and leaves of Momordica charantia. Fitoterapia. 2014;95:75-82.

105. Kumar S, Pandey AK. Chemistry and Biological Activities of Flavonoids: An Overview. Sci World J. 2013;2013:1-16.

106. Patel S, Patel T, Parmar K, Bhatt Y, Patel Y, Patel NM. Isolation, characterization and antimicrobial activity of charantin from Momordica Charantia Linn. fruit. Int J Drug Dev Res. 2010.

107. Gupta RC, Chang D, Nammi S, Bensoussan A, Bilinski K, Roufogalis BD. Interactions between antidiabetic drugs and herbs: an overview of mechanisms of action and clinical implications. Diabetol Metab Syndr. 2017;9.

108. Akihisa T, Higo N, Tokuda $\mathrm{H}$, et al. Cucurbitane-Type Triterpenoids from the Fruits of Momordica charantia and Their Cancer Chemopreventive Effects. J Nat Prod. 2007;70(8):1233-9.

109. Tan MJ, Ye JM, Turner N, et al. Antidiabetic Activities of Triterpenoids Isolated from Bitter Melon Associated with Activation of the AMPK Pathway. Chem Biol. 2008.

110. Kobori M, Nakayama H, Fukushima K, et al. Bitter gourd suppresses lipopolysaccharide-induced inflammatory responses. J Agric Food Chem. 2008;56(11):4004-11.

111. Huang W-C, Tsai T-H, Huang C-J, et al. Inhibitory effects of wild bitter melon leaf extract on Propionibacterium acnes-induced skin inflammation in mice and cytokine production in vitro. Food Funct. 2015;6(8):2550-60.

112. Tsai T-H, Huang W-C, Ying H-T, et al. Wild Bitter Melon Leaf Extract Inhibits Porphyromonas gingivalis-Induced Inflammation: Identification of Active Compounds through Bioassay-Guided Isolation. Molecules. 2016;21(4):454.

113. Yang WS, Yang E, Kim M-J, et al. Momordica charantia Inhibits Inflammatory Responses in Murine Macrophages via Suppression of TAK1. Am J Chin Med. 2018;46(2):435-52.

114. Bortolotti M, Mercatelli D, Polito L. Momordica charantia, a Nutraceutical Approach for Inflammatory Related Diseases. Front Pharmacol. 2019;10:486.

115. Chao C-Y, Sung P-J, Wang W-H, Kuo Y-H. Anti-inflammatory effect of Momordica charantia in sepsis mice. Molecules. 2014;19(8):12777-88.

116. Raish M, Ahmad A, Ansari MA, et al. Momordica charantia polysaccharides ameliorate oxidative stress, inflammation, and apoptosis in ethanol-induced gastritis in mucosa through NF-kB signaling pathway inhibition. Int $\mathrm{J}$ Biol Macromol. 2018;111:193-9.

117. Raish M. Momordica charantia polysaccharides ameliorate oxidative stress, hyperlipidemia, inflammation, and apoptosis during myocardial infarction by inhibiting the NF- $\kappa$ B signaling pathway. Int J Biol Macromol. 2017;97:544-51.

118. Rathee $P$, Chaudhary $H$, Rathee $S$, Rathee D, Kumar V, Kohli K. Mechanism of action of flavonoids as anti-inflammatory agents: a review. Inflamm Allergy Drug Targets. 2009;8(3):229-35. 
119. Soo May L, Sanip Z, Ahmed Shokri A, Abdul Kadir A, Md Lazin MR. The effects of Momordica charantia (bitter melon) supplementation in patients with primary knee osteoarthritis: A single-blinded, randomized controlled trial. Complement Ther Clin Pract. 2018;32:181-6.

120. Ifeantyi AM, Eboetse YO, Ikechukwu DF, Adewale OA, Carmel NC, Olugbenga OA. Effect of momordica charantia on estrous cycle of sprague-dawley rats. Pacific J Med Sci. 2011;8(1):37-48.

121. Deng $Y Y, Y_{i} Y$, Zhang $L F$, et al. Immunomodulatory activity and partial characterisation of polysaccharides from Momordica charantia. Molecules. 2014.
122. Kamaraj C, Kaushik NK, Rahuman AA, et al. Antimalarial activities of medicinal plants traditionally used in the villages of Dharmapuri regions of South India. J Ethnopharmacol. 2012;141(3):796-802.

123. Amorim CZ, Marques AD, Cordeiro RSB. Screening of the antimalarial activity of plants of the Cucurbitaceae family. Mem Inst Oswaldo Cruz. 1991;86(suppl 2):177-80.

124. I BR, A MO, I AA, W OO. Antidiarrhoeal activity of aqueous leaf extract of Momordica charantia in rats. J Pharmacogn Phyther. 2011;3(1):1-7.

\section{GRAPHICAL ABSTRACT}

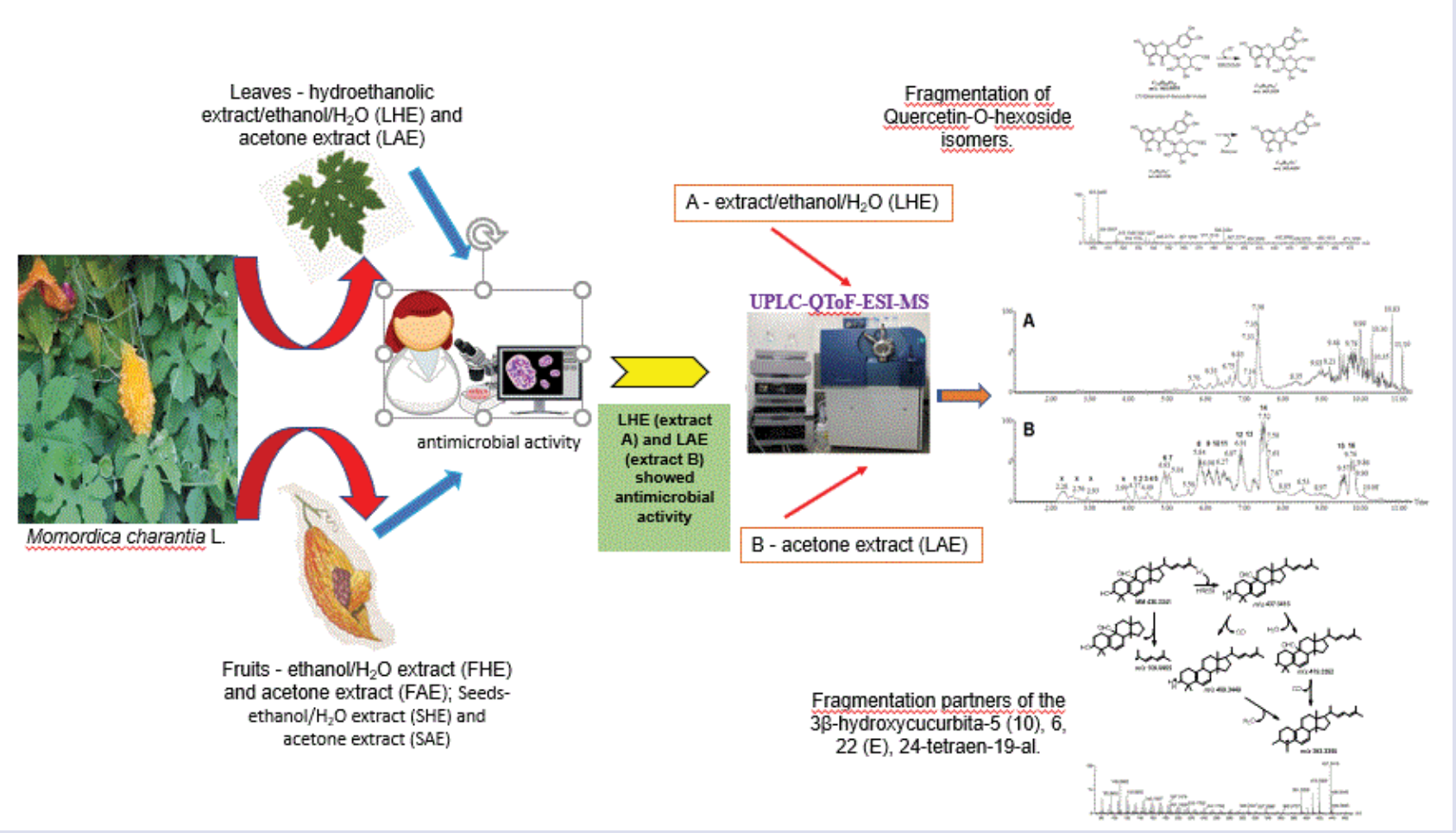

\section{ABOUT AUTHORS}

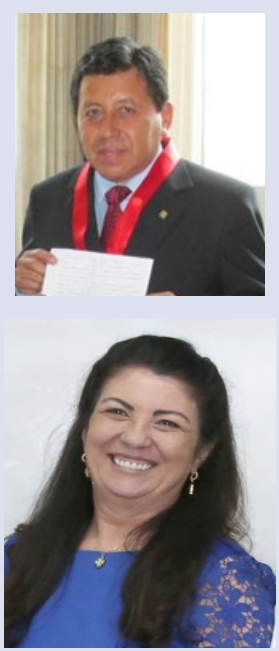

\section{SAGASTEGUI GUARNIZ WILLIAM ANTONIO}

Full Professor in the Department of Pharmacology of the Universidade Nacional de Trujillo, Perú since 1993 - to date. I am a licenced Pharmaceutical chemist. Lectures at the Post-Graduate School of Universidade Nacional de Trujillo. Has bachelor in pharmaceutical chemistry 1988. Masters in Chemical Sciences, 1999. Doctorate in Biomedical Sciences, Post-Graduate School of the Universidade Nacional de Trujillo, 2010. Doctorate Studies at Universidade Federal Do Ceará, Brazil, 2015-2018. I am actively involved in research and has presentations in many scientific meetings.

\section{MARY ANNE MEDEIROS BANDEIRA}

Mary Anne Medeiros Bandeira holds a degree in Pharmacy from the Federal University of Ceará (1981), a specialist in Pharmaceutical Chemistry (1985) from the Federal University of Minas Gerais, Master's degree (1993) and PhD (2002) in Phytochemistry from the Federal University of Ceará. She teaches Pharmacognosy, Phytotherapy and Phytochemistry at undergraduate and postgraduate levels at the Federal University of Ceará since 1995. Coordinator of the State Committee on Phytotherapy of Ceará and member of the Brazilian Committee on Medicinal Plants. Has experience in Pharmacy, focusing on Green Pharmacies, with research interest in the following areas: Phytotherapy in Public Health, Pharmacovigilance, Quality Control of Medicinal and Phytotherapeutic Plants and Phytochemistry of Natural Products. 


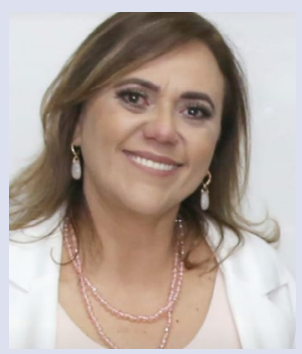

\section{KARLA DO NASCIMENTO MAGALHÃES}

Karla do Nascimento Magalhães holds a degree in Pharmacy from the Federal University of Ceará - UFC (1999), a Master in Pharmacology from the Faculty of Medicine of the Federal University of Ceará (2013) and a PhD in Development and Technological Innovation in Medicines from UFC (2019). Pharmacist at Fortaleza City Hall, Member of the State Committee of Phytotherapy of Ceará, Pharmacy of the Medicinal Plants Garden Professor Francisco José de Abreu Matos / UFC. Has experience in Clinical Pharmacy, Clinical Toxicology, Hospital Pharmacy and Ethnopharmacology.

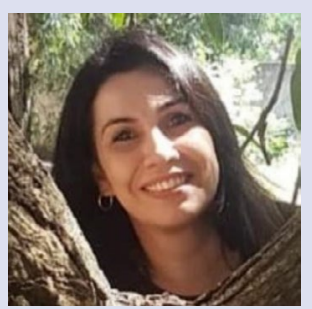

\section{KELLEN MIRANDA SÁ}

Kellen Miranda Sá graduated from the Federal University of Ceará (2000), Master in Public Policy and Higher Education Management (2016), Specialist in Natural Products of Plants and Derivatives, Specialist in Hospital Administration. Pharmaceutical Garden of Medicinal Plants Francisco José de Abreu Matos at the Federal University of Ceará, Member of the State Committee on Herbal Medicine of Ceará, Member of the Alliance of International Aromatherapists (AIA-USA), Member Brazilian Association of Aromatherapy and Aromatology (Abraroma). Has experience in Phytotherapy, Aromatherapy, Pharmacotechnics, Cosmetology, Pharmaceutical Clinic and Hospital Pharmacy.

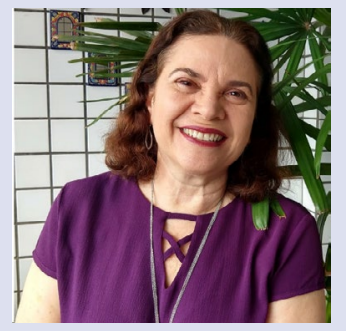

\section{MIRIAN PARENTE MONTEIRO}

Graduated in Pharmacy in the Federal University of Ceara (1982), Master degree in Inorganic Chemistry from the Federal University of Ceará (1987), PhD in Pharmacology at Federal University of Ceará (2000). Currently Associate Professor, level IV at Federal University of Ceará. Experience in Pharmacy with research themes in the following areas: pharmaceutical care, rational use of medicines, pharmaceutical assistance and drug information center. Collaborator Professor of Doctorate at the Postgraduate Program in Development and Technological Innovation in Medicines. Coordinator of the Group on Prevention of Inappropriate Use of Medicines, an Extension Program of the Federal University of Ceará.

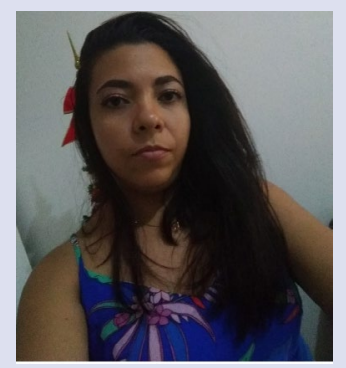

\section{PATRICIA GEORGINA}

Bachelor in Chemistry from the Federal University of Ceará (2010), Master (2012) and Doctorate (2018) in Chemistry with concentration in Organic Chemistry from the same University. She is the current laboratory technician/phytochemist at the Laboratory of Natural Products in the Abreu Matos Medicinal Plant Garden of the Federal University of Ceará. She currently executes research projects aimed at the phytochemical characterization of medicinal plants. Has experience in Chemistry, focusing on Organic Chemistry, particularly focused on Natural Products, Organic Synthesis and Medicinal Plants.

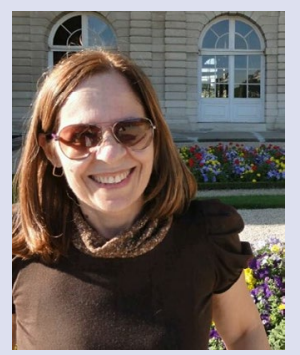

\section{NADIA ACCIOLY PINTO NOGUEIRA}

Bachelor Degree in Industrial Chemistry from the Federal University of Ceará (1979), Master in Food Technology (1985) and PhD in Biochemistry from from the same University (1999). Full Professor at the Federal University of Ceará where she lectures at undergraduate and postgraduate levels. Has experience in Microbiology and Molecular Biology, with emphasis on Antimicrobial Activity and Bacterial Resistance. She is coordinator of the Applied Microbiology Research Laboratory and of the Molecular Biology Laboratory of Microorganisms of the Federal University of Ceará.

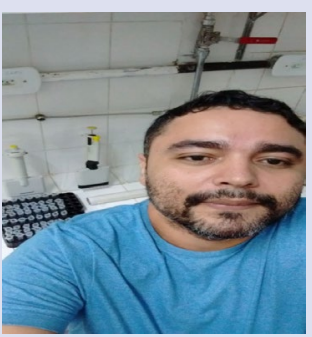

\section{GLEILTON WEYNE PASSOS SALES}

Graduated in Pharmacy (Clinical Analysis), Master and PhD in Pharmaceutical Sciences from the Federal University of Ceará. Member of the Research group of the applied microbiology laboratory at Pharmacy (LabMicro). Member of the Ateneu Faculty graduate faculty. Has experience in Community Pharmacy, teaching at technical and higher levelsHis research interests are: antimicrobial and antifungal activity of natural products and mechanism of action. 


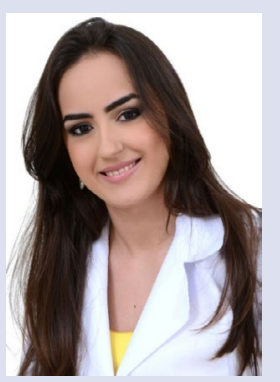

\section{HILANIA VALÉRIA DODOU}

Graduated in Pharmacy from the Federal University of Ceará - UFC (2014). Specialist in Clinical Cytology at Ateneu College (2015) and in Higher Education Teaching at Integrated College of Brazil (2016). Master in Pharmaceutical Sciences from UFC (2017). She is currently a PhD student in the Post-Graduate Program in Pharmaceutical Sciences at UFC. Has experience in Pharmacy, focusing on Applied Microbiology, developing research with antimicrobial activity, mechanism of action and toxicity of natural products

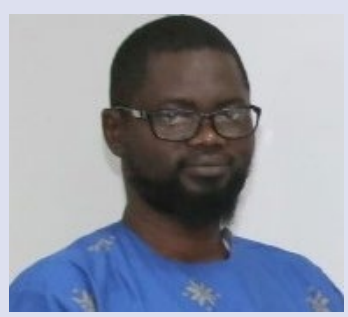

\section{SIKIRU OLAITAN BALOGUN}

I have Bachelor (Hons) and Maters (Biochemistry) degrees from Olabisi Onabanjo University, AgoIwoye (Nigeria) (Formerly Ogun State University) and a PhD in Health Sciences (Pharmacology area) from the Faculty of Medicine of the Universidade Federal de Mato Grosso (UFMT). I had lectured at Kampala International University, Uganda (2006 - 2010). Had taught and currently teaching Biochemistry, Pharmacology, Molecular Biology and other related medical sciences courses at both undergraduate and post-graduate levels. Presently lecturer at Faculdade Noroeste do Mato Grosso- AJES. Over 13 years of teaching and research experience. My teaching and research experience covers biochemistry, molecular biology, molecular epidemiology (microbiology), natural product pharmacology, ethnopharmacology, ethnobotanical, medicinal plant bioprospecting, in vitro and in vivo experimental models. Research interests includes molecular epidemiology (bacterial resistance), antimicrobial, anti-inflammatory, anti-ulcer, activities, ethnobotany, ethnopharmacology and toxicity studies of medicinal plants.

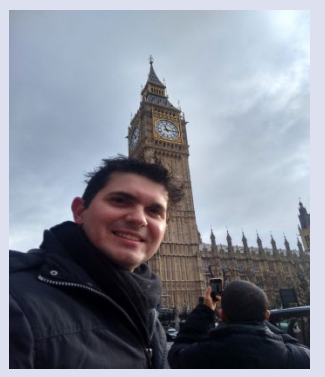

\section{Paulo Riceli Vasconcelos Ribeiro}

Bachelor Degree in Industrial Chemistry from the Federal University of Ceará - UFC (2008), Master (2010) and Ph.D. in Natural Products from UFC (2016). Currently works with an emphasis on Natural Product, mainly in plant and fungal research. He works as Analyst B at the Brazilian Agricultural Research Corporation, Embrapa. Has experience in mass spectrometry using instruments UPLC-QTOF, Waters, and LC-Ms-Iontrap, Agilent, Infrared and in High-Performance Liquid Chromatography.

Cite this article: Guarniz WAS, Canuto KM, Ribeiro PRV, Dodou HV, Magalhaes KN, Sa KM, et al. Momordica Charantia L. Variety from Northeastern Brazil: Analysis of Antimicrobial Activity and Phytochemical Components. Pharmacog J. 2019;11(6):1312-24. 